\title{
Med kvinderne til velfærdsstaten \\ - Kvindeorganisering i Danmark 1920-1940
}

Af Hilda Rømer Christensen

Kpindeorganisationerne ydede et markant, men langt ben overset bidrag til pelfardsstatens etablering $i$ mellemkrigstiden. Baide nair det gjaldt debatten og nair det gjaldt beslutningsprocesserne. Kpindeorganisationernes indsats ses $i$ lyset af den danske pelfardsstatsforskning og den komparative forskning om kvindeorganisering og pelfardsstat.

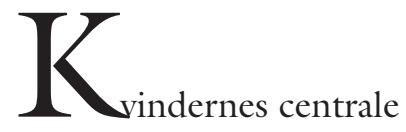

placering i velfærdsstatens institutioner førte i begyndelsen af 1990erne til en ophedet debat i de danske medier og blandt danske kønsforskere. Det blev hævdet, at kvinderne sidder tungt på omsorgen i vælfærdssamfundet, som de dominerer med kvindelige værdier og idealer. Dermed marginaliseres mandlige værdier og adfærdsformer, og som konsekvens presses mændene over i en nyliberal mandlighed. Yderligere blev det hævdet, at kvinderne vil bevare vælfærdsstaten i dens nuværende form, og at de dermed hindrer en markedsorienteret fornyelse, og i videre forstand en dansk integration i EU. ${ }^{2}$

Selvom velfærds-debatten her omkring årtusindeskiftet har andre fokuspunkter går denne kønsmæssige polarisering igen som en skjult dagsorden. Både på det symbolske niveau, hvor den offentlige velfærd forbindes med tradition, bløde værdier og det feminine, mens udlicitering og kommercialisering konnoteres med fornyelse, handle- 
kraft og det maskuline. Ærindet for er ikke mindst, at gøre Danmark værdigt til at deltage $\mathrm{i}$ den igangværende globalisering, kommercielt såvel som politisk. Og når det gælder den konkrete vælgerappel på disse spørgsmål er det sigende, at partiet Venstre som den mest energiske fortaler for de mandligt konnoterede dyder, privatisering og udlicitering af velfærdsydelserne og øget europæisk integration, p.t. har meget vanskeligt ved at rekruttere kvinder både som politikere og vælgere.

Sammenhængen mellem køn, velfærdsstat og politisk kultur, er imidlertid ikke noget, der udelukkende vedrører historien efter 1945. Jeg vil i det følgende fokusere på denne sammenhæng ved at trække nogle linjer mellem kvinders organiserede bestræbelser og den tidlige velfærdsstat i mellemkrigstiden. Med andre ord vil jeg vise, at kvindernes engagement $\mathrm{i}$ velfærdsstaten har en lang historie, som ikke kan reduceres til politisk snæversyn eller aktuelle interesser i feminin magtudøvelse. Hverken dengang eller nu.

\section{KVINDEORGANISATIONER OG VELFÆRDSSTATSFORSKNING}

Kvindeorganisationerne i Danmark kan lidt frit efter Olive Banks - deles i tre retninger med rødder $\mathrm{i}$ den specifikke danske version af protestantisme (vækkelsesbevægelse), oplysningstænkning og socialisme. Formålet med det følgende er dobbelt - og sikkert alt for ambitiøst: Nemlig dels at skitsere, hvorledes de forskellige kvindeorganisationer præsenterede sig i den politiske kultur, med hvilken styrke og med hvilke alliancepartnere. Dels er formålet at angive nogle af forbindelseslinjerne mellem kvindeorganisationerne og tilløbene til velfærdsstatens konsolidering i mellemkrigstiden. Hvilke initiativer tog kvinderne og med hvilke motiver? På hvilke områder nåede de deres mål? Hvilke konsekvenser har kvindeorganisationernes indsats i mellemkrigstiden haft for efterkrigstidens velfærds- stat? Hvilken kontinuitet kan der spores fra mellemkrigstiden til perioden efter 1945, når det gælder kvinders organiserede indsats?

Som en ramme for artiklen vil jeg godt skitsere og problematisere mindst to strømninger i den aktuelle forskning om velfærdsstaten. For det første den aktuelle historiske forskning om velfærdsstaten og dens kønsblindhed og for det andet den internationale, navnlig den amerikanske, forskning om kvinder og velfærdsstat.

Når det gælder den aktuelle historiske forskning om velfærdsstaten og dens kønsblindhed vil jeg tage udgangspunkt i Søren Kolstrups Velfardsstatens rødder. Fra kommunesocialisme til folkepension. Ikke alene, fordi emnet lægger op til en inddragelse af køn og kvinder. Men også fordi kønsblindheden og sikkert også argumenterne herfor (se Søren Kolstrups kommentar i dette nummer af KKF) er symtomatisk for en hel generation af yngre og trendsættende velfærdsstatsforskere. Et dugfrisk eksempel på dette er et af de seneste numre af det engang så "alternative" historiske tidsskrift, Den Jyske Historiker med temaet Den danske velferdsstat $i$ international belysning. På omslaget et billede med en familie - kernefamilie naturligvis - på vej til stranden, hvilket anslår, at forbindelse mellem familie, køn og velfærdsstat er central. Men indpakningen viser sig at være en ren gimmick: ikke en eneste artikel, tematiserer eller integrerer familie, kvinder eller køn i substantiel forstand. Det er næsten overflødigt at nævne, at alle forfatterne er mænd. ${ }^{3}$

Men tilbage til Søren Kolstrup. Hans fortjeneste er, at historisere opkomsten af velfærdsstaten som et fænomen med rødder tilbage til den statslige socialpolitik i slutningen af sidste århundrede - over kommunesocialismen i århundredets første årtier til 1930ernes konsolidering af rets- universalistiske principper - og op til folkepensionsreformen i 1956. Han går i løbet af analysen i kødet på gængse struktur- og aktør- 
teorier (industrialiserings- moderniserings teorier om velfærdsstaten som et socialdemokratisk projekt osv.). Kolstrups tese er, at den danske velfærdsstat er opstået som en langvarig glidende reformproces i et klassesamfund med relativt mange selvstændige og en politisk kultur præget af politiske klassekompromisser. Han peger videre på socialdemokratiets initierende rolle. De omfattende sociale eksperimenter i en række danske provinsbyer - populært kaldet kommunesocialismen - tilskrives en vigtig laboratorierolle. De lokale reformer af sundheds- og skolevæsen, som var skattefinansierede og universelle, blev senere almengjort i den nationale lovgivning. Altsammen argumenterer Kolstrup tilsyneladende solidt og overbevisende for.

Fra en kvindehistorisk synsvinkel er det imidlertid foruroligende, at det lykkes ham at skrive en bog på næsten 500 sider uden at inddrage kvindernes organiserede bidrag til denne udvikling. Mens både de politiske partier, navnlig socialdemokratiets strategier, får en indgående behandling, bliver de civile organisationer inddraget under ét som "velfærdsorganisationer". Tesen er, at disse organisationer havde et lokalt praktisk spillerum, men at de med enkelte undtagelser var for svage til at spille nogen rolle for den nationale lovgivning. Mit ærinde er ikke overraskende, at vise, at kvinders organiserede bestræbelser havde en større betydning end mange (navnlig mandlige) historikere er opmærksomme på, og endvidere at diskutere de empiriske og teoretiske konsekvenser af dette. 4

Mit andet afsæt er den internationale, navnlig den amerikanske, forskning om kvinder og velfærdsstat i komparativt perspektiv, bl.a. representeret ved Seth Koven og Sonya Michel. 5 De har vist, at der var et sammenfald mellem kvinders reform bestræbelser og velfærdsstaternes opkomst. De har endvidere dokumenteret, hvordan kvindeorganisationerne og velfærdsinitiativerne påvirkede og forstærkede hinanden, navnlig når det gjaldt foranstaltninger for mødre og børn. Samtidig mener jeg at den tilknyttede begrebsdannelse og positive valorisering af begreber som "maternalism" og "maternalist politics" kan være med til at fastlåse dikotomien mellem moderskabs- og ligestillingspolitik. En dikotomi, som siden mellemkrigstiden har været fremherskende både politisk og begrebsmæssigt i USA, men som næppe er dækkende for den danske og nordiske kontekst.

Koven og Michel har i forlængelse af den komparative tilgang formuleret teser om sammenhængen mellem kvindeorganisationers styrke og den nationale politiske kultur. De har peget på det paradoksale faktum, at der i lande med en stærk stat, et veludviklet bureaukrati og med traditioner for statsintervention som f.eks. Tyskland og Frankrig, har været mindre plads til og succes for organiserede bestræbelser fra kvindeside end i lande med såkaldt svagere traditioner for statsintervention som USA og Storbritannien.

Når jeg bruger termen paradoksal er det fordi der hverken aktuelt eller historisk synes at være kongruens mellem det påståede spillerum for kvindeorganisationerne og de faktiske betingelser for kvinder og børn i disse lande. Hvordan stiller sagen sig i Danmark? Hvad har eksistensen af en relativ stærk arbejderbevægelse og en stadig mere intervenerende stat betydet? Hvilken rolle har kvindeorganisationerne spillet i denne proces? Er det rimeligt at tale om den danske kvindebevægelse som specielt svag eller afvigende som Koven og Michel lægger op til i deres sondering? 6

\section{DANSKE KVINDEORGANISATIONER I MELLEMKRIGSTIDEN}

Generelt var de danske kvindeorganisationer præget af betragtelige medlemstal i mellemkrigstiden. Det var årtier hvor ikke alene elitens kvinder organiserede sig, men også kvinder fra bredere lag. De hjemmearbejdende husmødre organiserede sig i husmororganisationer på landet og i byerne, 
unge kvinder meldte sig $\mathrm{i}$ stort tal ind $\mathrm{i}$ KFUK og i de (kønsblandede) grundtvigianske ungdomsforeninger og i mindre udstrækning i de politiske partiers ungdomsarbejde. Også arbejderkvinder og kvinder i forskellige professioner organiserede sig i stigende grad i faglige organisationer og $\mathrm{i}$ det spirende kvindearbejde $\mathrm{i}$ de politiske partier.

Et andet bemærkelsesværdigt træk er, at flere af organisationerne, f.eks. Dansk Kvindesamfund og KFUK, via deres forgrenede foreningsnet, havde fodfæeste både på landet og i de mindre byer og i København. Dette til forskel fra de angelsaksiske lande, og muligvis i det øvrige Norden, hvor både kvindesag og kristeligt ungdomsarbejde som KFUK var udprægede city-fænomener.

\section{RELIGIØSE KVINDEORGANISATIONER}

Vækkelserne i det 19. århundrede betød at også kvinderne fik deres organisatoriske netværk. I Danmark var der to hovedstrømninger - den grundtvigianske og den indre missionske. Mens nogle af de grundtvigianske kvinder tidligt sluttede sig til kvindesagen i skikkelse af Dansk Kvindesamfund og andre senere blev primusmotorer i husholdnigsorganisationerne, blev Indre Missions kvinder bl.a. organiseret i kvindekredse i Indre Mission og i det mere selvstændige KFUK. Dansk KFUK blev oprettet i 1883 og havde i mellemkrigstiden, hvor medlemstallet kulminerede omkring 30.000, status af Danmarks største kvindeorganisation. Selv om KFUK ikke var kvindepolitisk engageret og ikke åbent sigtede mod xndring af samfundets overordnede strukturer, så udgjorde en række af KFUKs aktiviteter en forform til velfærdssamfundets institutioner. $^{7}$

Dansk KFUK oprettede f.eks. i 1922 "KFUKs Velfærdsarbejde" i København. Det sigtede på en bred vifte af nødstedte kvinder. Der blev oprettet et banegårdsarbejde, som skulle modtage og hjælpe kvinder, der kom til hovedstaden. Desuden blev der lavet en klinik for unge kvinder med kønssygdomme og et hjem for "unge holdningsløse" kvinder. Endelig blev der etableret en natoptagelse - et datidens krisecenter for ulykkeligt gifte kvinder, der blev mishandlet af deres mænd. I 1926 oprettede KFUK desuden en uautoriseret socialarbejderuddannelse - en sociallinje i tilknytning til deres sekretæruddannelse. En af medarbejderne i KFUKs velfærdsarbejde, Manon Lüttichau, var i 1937 blandt initiativtagerne til oprettelsen af Den sociale Højskole, som var den første statslige uddannelsesinstitution for socialrådgivere $\mathrm{i}$ Danmark.

Historien viser både hen til KFUK som pioner på det institutionelle plan og til at nogle af de kvinder som startede i KFUK senere overskred det religiøst-filantropiske univers og gik ind i socialpolitiske beslutningsprocesser.

Også når det gjaldt de berømmede “røde byer" - eller kommunesocialismen - var der i hvert fald en kvinde fra dette miljø, som spillede en nøglerolle. Kommunelærerinde Johanne Blom blev i 1909 indvalgt i Københavns Borgerrepresentation på en kristelig social liste. Samme år støttede hun Socialdemokratiets kandidat til socialborgmesterposten, mod de borgerlige. Fra 1913 til 1917 fungerede hun som tunge på vægtskålen i Borgerrepræsentationen, hvor Socialdemokraterne manglede et mandat $i$ at have flertal. Hun allierede sig med Socialdemokraterne og var med til at sikre en række sociale reformer, som indførelse af fælles enhedsskole og ophævelsen af betalingsskoler i København og udvidet skolebespisning (Wiinblad 1921, Jensen 1945).

Johanne Bloms baggrund var blandt andet den kristelige Kvindevalgretsforening, der blev oprettet i 1908 og som alene i København havde 800 medlemmer. Foreningen mobiliserede kvinder med tilknytning til Indre Mission og KFUK i kampen for stemmeretten. Da foreningen ophørte i 1913, blev medlemmerne opfordret til at gå ind i Dansk Kvindesamfund, hvilket viser hen til fælles fodslag med det kvindesaglige 
arbejde. I mellemkrigstiden var der fortsat forbindelseslinjer mellem ledende KFUKere og Dansk Kvindesamfund og der foregik et vist samarbejde omkring sociale og moralske spørgsmål. Dog var de fleste kristelige kvinder modstandere af udvidet adgang til prævention og abort og gifte kvinders lønnede arbejde, som blev et varmt kønspolitisk emne i 1930erne.

Det kristeteligt sociale engagement, som kom til udtryk i og omkring KFUK skete i princippet med en nedarvet skepsis overfor arbejderbevægelsen og Socialdemokratiet og det verdsligt-politiske liv. De KFUKere, der blev partipolitisk aktive, blev det i borgerlige partier, som ofte havde en ambivalent holdning til socialpolitiske foranstaltninger og sjældent havde øje for de grupper, som kvinderne fik primær erfaringer med i deres institutionelle arbejde (Christensen 1995).

Dette til forskel fra de angelsaksiske KFUKer, som forholdt sig meget mere bevidst og åbent både overfor fagbevægelsen og kvinders materielle vilkår. I Storbritannien foregik der en livlig udveksling mellem britisk Labour og britisk KFUK og nogle af de første kvindelige Labour parlamentsmedlemmer havde nær tilknytning til KFUK. ${ }^{8}$ I USA opfordrede KFUK ledelsen direkte kvinder til at lade sig fagligt organisere i de socialistiske fagforeninger omkring 1920 ligesom amerikansk KFUK var pionerer når det gjaldt arbejderundervisning for kvinder. Ledende amerikanske KFUKere blev desuden knyttet til statsadministrationen i begyndelsen af 1920erne og var med til at lancere socialpolitiske initiativer for kvinder og børn. Når det gælder en organisation som KFUK forekommer Koven og Michels tese altså ikke helt misvisende. I Danmark betød tilstedeværelsen af en magtfuld socialistisk og religiøs indifferent arbejderbevægelse sammen med organisationens i princippet apolitiske verdensanskuelse, at KFUKernes engagement sjældent overskred det individuelt filantropiske. Og

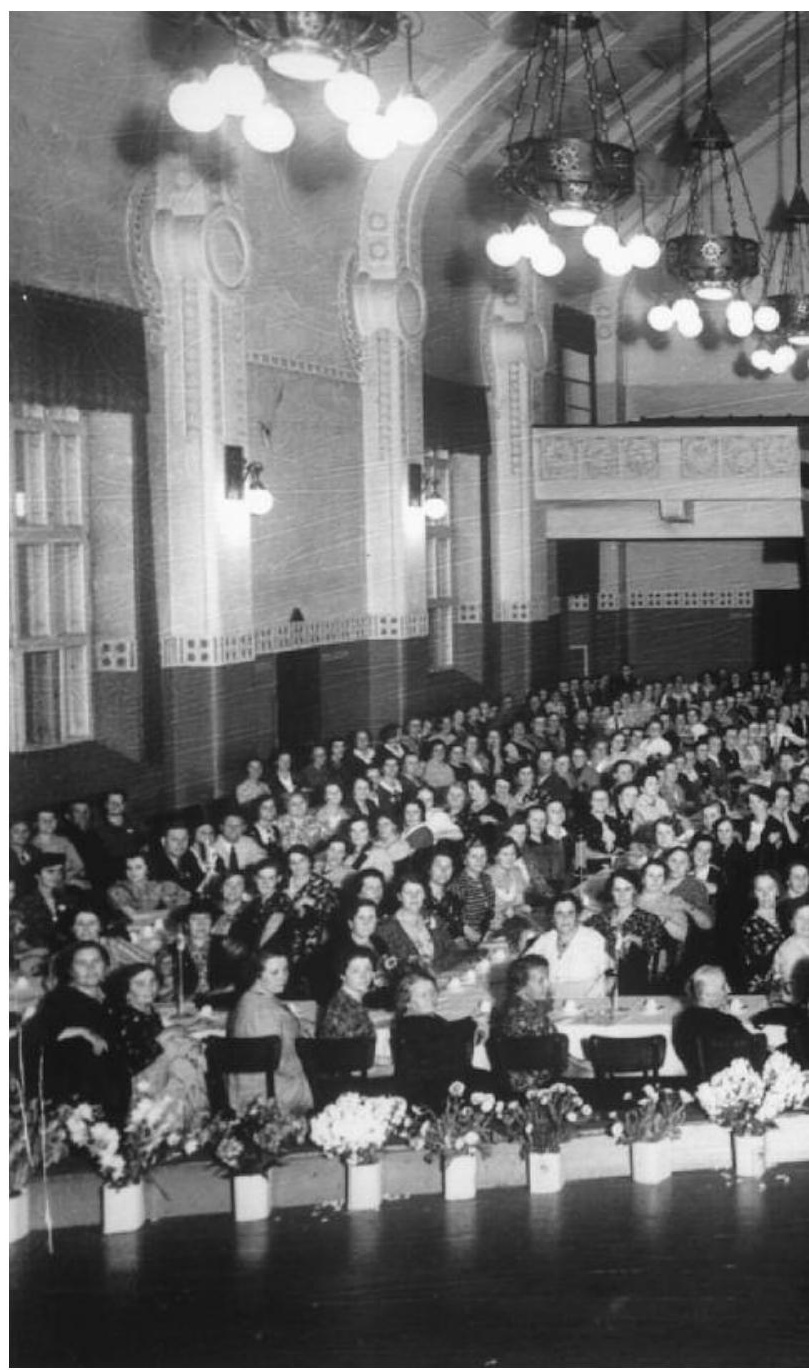


hvis det gjorde, var det næsten altid en utilsigtet sideeffekt.

\section{HUSHOLDNINGSORGANISATIONERNE}

Husholdningsorganisationerne opstod i kølvandet af 1 . Verdenskrig. Til forskel fra de kvindesaglige og religiøse organisationer kom den geografiske modsætning mellem land og by til at præge den måde, som husmødrene organiserde sig på. Byhusmødrene organiserede sig i 1920 i "De danske Husmoderforeninger" og landbokvinderne i "De samvirkende danske Husholdningsforeninger på Landet" i 1921. Husholdningsorganisationerne sigtede ideelt set mod at organisere alle husmødre "uden Hensyn til Stand, Stilling og politiske Anskuelser" men i realiteten blev kernemedlemmerne mellemlagene/småborgerskabets kvinder i byerne og på landet (Christensen og Nielsen 1985). Mens de kvindesaglige organisation(er) medlemsmæssigt stagnerede i mellemkrigstiden, var husholdningsorganisationerne navnlig i 1930erne præget af stor tilgang. Husholdningsforeningerne på landet havde i 19317.000 medlemmer, i 193811.500 og i 1946 næsten 25.000 medlemmer $i$ et vidt forgrenet foreningsnet. Husholdningsorganisationerne byggede på det, der er kaldt professionaliseret særart. Formålet var dobbelt: faglig oplysning og kulturel opdragelse af kvinderne. Den faglige oplysning hvilede på et videnskabeligt grundlag og man brugte flittigt eksperter i og udenfor universitetet som skribenter og foredragsholdere.

1930erne var præget af en voldsom interesse for husholdningsspørgsmålet, der kom til udtryk i flere kommissionarbejder bl.a. om husholdningsundervisning og husassistentspørgsmålet. Desuden blev der vedtaget flere love, bl.a. loven om Statens Husholdningsråd i 1935 og love om husholdningsundervisningens organisering. 9 Husholdningsorganisationere blev inddraget i dette arbejde og dermed i de statslige beslutningsstrukturer. Denne integration i beslutningsprocesserne betød på den ene side magt og indflydelse og på den anden side ansvarlighed og loyalitet. Når husholdningsorganisationernes arbejde lykkedes på dette punkt tyder det på, at staten og husmødrene havde sammenfaldende interesser $i$ at forbedre og professionalisere det traditionelle kvindearbejde i familien, som havde betydning for børnenes og nationens sundhedstilstand - og i et større perspektiv i at fastholde den traditionelle arbejdsdeling mellem mænd og kvinder. De var her i overensstemmelse med stærke politiske kræfter - fra højre til venstre, som bevidst og ubevidst ønskede at bevare fordelingen af magt og arbejde mellem kønnene.

Samtidig fik kvinderne her mulighed for i samarbejde med (mandlige) og kvindelige eksperter at artikulere socialpolitiske interesser, ikke mindst omkring varetagelse af moderskabet. F.eks. støttede Husholdningsorganisationerne loven om sundhedsplejersker, som blev vedtaget i 1937, mens deres mandlige klasse- og partifæller var mere skeptiske. Det var således bøndernes parti - Venstre - som fastholdt at sundhedsplejerskeordningen skulle være frivillig. Det betød at ordningen aldrig blev realiseret i mange landkommuner. ${ }^{10}$

Husholdningsorganisationerne er ofte blevet modstillet de kvindesaglige organisationer når det gjaldt den professionaliserede særartsideologi. For Danmarks vedkommende er denne modstilling ikke holdbar. Dansk Kvindesamfund talte både mange (grundtvigianske) husmødre blandt sine medlemmerne ligesom der tidligt opstod en alliance med professionelle husholdningskvinder, husholdningslærere bl.a. Dansk Kvindesamfund havde allerede tidligt i århundredet husholdsningssagen på programmet og arbejdede i mange år på at oprette et videnskabeligt husholdningsfakultet. Dansk Kvindesamfund gik mere konsekvent ind for en professionaliserings linje end husholdningsorganisationerne, men den grundlæggend ideologi om arbejdsdelingen i familien var som i samfundet iøvrigt. 
Et mindretal af ultrakonservative kvinder $\mathrm{i}$ både Dansk Kvindesamfund og i byernes Husmorforeninger gik ind for huslig værnepligt. I 1937 henvendte en gruppe kvinder sig til justitsministeriet med krav om tvungen huslig værnepligt, som indebar, at alle kvinder mellem 14 og 18 år skulle have en 1-årig uddannelse i husligt arbejde. Kvinder under 20 år skulle desuden forbydes adgang til arbejde $\mathrm{i}$ fabrikkerne indtil de havde gennemført den huslige værnepligt. Forslaget vandt aldrig - som f.eks. i Nazityskland - genklang i kvindeorganisationerne (Bridental 1994). Men tankegangen sneg sig ind andre steder, f.eks. i hetzen mod gifte kvinders arbejde og i en række mere eller mindre tvungne statslige foranstaltninger for arbejdsløse kvinder. Husholdningskurser og ungdomslejre skulle medvirke til at overføre unge kvinder fra industri og handel til husholdningserhvervet. Alt i alt blev de danske husholdningsorganisationer ikke, som f.eks. de tyske, influeret af 1930ernes autoritære ideologier. De blev inrulleret i de politiske beslutningsprocesser og var på den måde tidligt medvirkende til den gryende velfærdsstat og de korporative beslutningsprocesser. I nogen grad i modsætning til konservative og ultraliberale mænd i deres egne rækker.

\section{SOCIALISTISKE}

\section{KVINDEORGANISATIONER}

De almindelige arbejderkvinder organiserede sig i arbejderbevægelsens egne organisationer. De erhvervsaktive i fagbevægelsen og de socialdemokratiske husmødre i de socialdemokratiske kvindeudvalg. ${ }^{11}$ Disse kvindeudvalg blev oprettet i slutningen af 1920erne i tilknytning til de lokale partiforeninger. Partiledelsen stillede sig i lang tid meget skeptisk overfor arbejdet og afviste kvindernes ønske om mere selvstændighed, bl.a. i form af en landsledelse og et selvstændigt blad. Det danske Socialdemokrati var i den henseende mere restriktivt end partifællerne i det øvrige Norden. Først i
1943 fik kvindeudvalgene egen sekretær og først i slutningen af 1940erne fik de egen landsledelse og et selvstændigt blad.

På trods af vanskelighederne ekspanderede kvindeudvalgene fra 15 i 1929 til 116 i 1940. Diskussionen om et mere selvstændigt kvindearbejde, efter svensk model, dukkede op fra tid til anden, men det blev den østrigske model med kvindeudvalgende tæe knyttet til og kontrolleret af partiapparatet, som blev den bærende. Fraværet af en stærk selvstændig socialdemokratisk kvindebevægelse betød, at flere af de socialdemokratiske topkvinder engagerede sig i Dansk Kvindesamfund i mellemkrigstiden.

De socialdemokratiske kvindeudvalg iværksatte et stort stykke oplysningsarbejde om politiske og sociale emner. Desuden støttede de aktivt forslagene om lettere adgang til prævention og seksualoplysning. Til gengæld var der, ligesom blandt de borgerlige kvinder, uenighed om abortspørgsmålet.

Oplysningsarbejdet reflekterede også at mange af medlemmerne var husmødre. I løbet af 1930erne kom der huslige emner og ernæringsdemonstrationer på programmet. De socialdemokratiske kvinder bakkede op om Statens Husholdningsråd fra 1935 som en kanal til at påvirke produktion og konsum og som et oplysningsorgan for arbejderhusmødrene.

Både de socialdemokratiske kvinder og Dansk Kvindesamfund kritiserede desuden den kønsmæssige slagside i det nye og omfattende lovkompleks "Socialreformen" fra 1933. Reformen bragte Danmark i front hvad angår skattefinansierede ydelser. Men universalismen havde i flere tilfælde kønsmæssig slagsside, både når det gjaldt kvinders pensioner og når det gjaldt offentlige tilskud til f.eks. børneinstitutioner. 12

Samtidig eksisterede der en stærk ligestillingstrend i det socialdemokratiske kvindemiljø. Det blev allerede synligt i 1910erne hvor socialdemokratiske kvinder etablerede en alliance med Dansk Kvindesamfund om- 
kring natarbejdsforbud og beskyttelseslovgivning for kvinder. I 1930erne gjaldt alliancen mellem de socialdemokratiske kvinder og Dansk Kvindesamfund kampen for gifte kvinders ret til arbejde. Arbejdet lykkedes i den forstand, at den socialdemokratiske partiledelse ved flere lejligheder proklamerede, at restriktioner af gifte kvinders erhvervsarbejde ikke harmonerede med socialistiske idealer. I 1934 blev gifte kvinders ret til erhvervsarbejde fastslået i partiprogrammet. Pà trods af dette blev der 1930ere igennem rapporteret om afskedigelsen af gifte kvinder på lokalt plan, også i socialdemokratiske kommuner.

De socialdemokratiske kvindeudvalg formåede ikke at opstille noget samlet kvindeprogram, hvilket både skyldtes modstanden fra de mandlige partifæller og den manglende tradition for samlede reformprogrammer i det danske socialdemokrati. De socialdemokratiske kvinder arbejdede ligesom det Øvrige parti med "single issues" på det socialpolitiske og arbejdsmarkedspolitiske felt. De sluttede ivrigt op om Befolkningskommissionen og dens mere samlede sociale reformplaner, som omfattede udbygget offentlig service for mødre og børnepasning og seksualoplysning, samt støtte til socialt boligbyggeri og huslejetilskud. ${ }^{13}$ Det var også en af de ledende kvindeudvalgskvinder, der stod i spidsen for foreningen Frie Børnehaver ved stiftelsen i 1939. Målet var at oprette alternativer til de religiøse Menighedsbørnehaver.

Loyaliteten mod partiapparatet og alliancerne med de socialliberale og borgerlige kvinder i Dansk Kvindesamfund betød, at de socialdemokratiske kvinder ikke allierede sig med de radikale kvinder på venstrefløjen, som i 1925 samlede sig i Arbejderkvindernes Oplysningsforening. Foreningen, der udsprang af 1920ernes radikale fagopposition, forsøgte at bygge bro mellem fagforeningspolitik og socialpolitik. Foreningen stillede meget moderne og radikale krav som tog hensyn til kvinder som både arbejdende og som mødre og krævede ligeløn, nedsat arbejdstid og udvidet barselsorlov. Desuden havde foreningen et livligt samarbejde med seksualreformbevægelsen og dens forgrundsfigur, Jonathan Leunbach. I 1929 indsendte Arbejderkvindernes Oplysningsforening et kontroversielt forslag til Folketinget om obligatorisk seksualoplysning i skolerne, præventionsrådgivning og ret til frivilligt moderskab. Under inspiration fra Norge forsøgte de også at få etableret seksualrådgivningsklinikker tilknyttet de lokale sygekasseforeninger. Da alle disse planer og forslag ikke lykkedes oprettede Foreningen sammen med Jonathan Leunbach en privat seksualrådgivningsklinik i København i 1932. Selvom foreningen på sit højdepunkt kun havde omkring 400 medlemmer havde den en betydelig agitatorisk effekt. Til forskel fra de socialdemokratiske kvinder havde foreningen sit eget blad, som blev redigeret af den prominente socialistiske agitator, lærerinden, Marie Nilesen.

Oprettelsen af de socialdemokratiske kvindeudvalg i 1929 kan på den måde ses som et forsøg på at dæmme op for den appel, som Arbejderkvindernes Oplysningsforening havde til arbejderkvinderne ikke mindst når det gjaldt seksualpolitiske krav. Arbejderkvindernes Oplysningsforening mistede sin udfarenhed og appel da den i begyndelsen af 1930erne mere åbentlyst blev et appendiks til Danmarks Kommunistiske Parti.

Selv om de socialdemokratiske kvinder og kvinderne i Arbejderkvindernes oplysningsforening i princippet ikke stod langt fra hinanden på afgørende punkter, foregik der ikke noget videre samarbejde mellem dem. Kvinderne følte sig i den henseende mere knyttet til deres respektive politiske miljøer. Først med den radikale socialistiske feminismes genopstån i den nye kvindebevægelse i 1970erne, blev de radikale krav til et liv, hvor man kunne forene arbejde og moderskab taget op igen. 


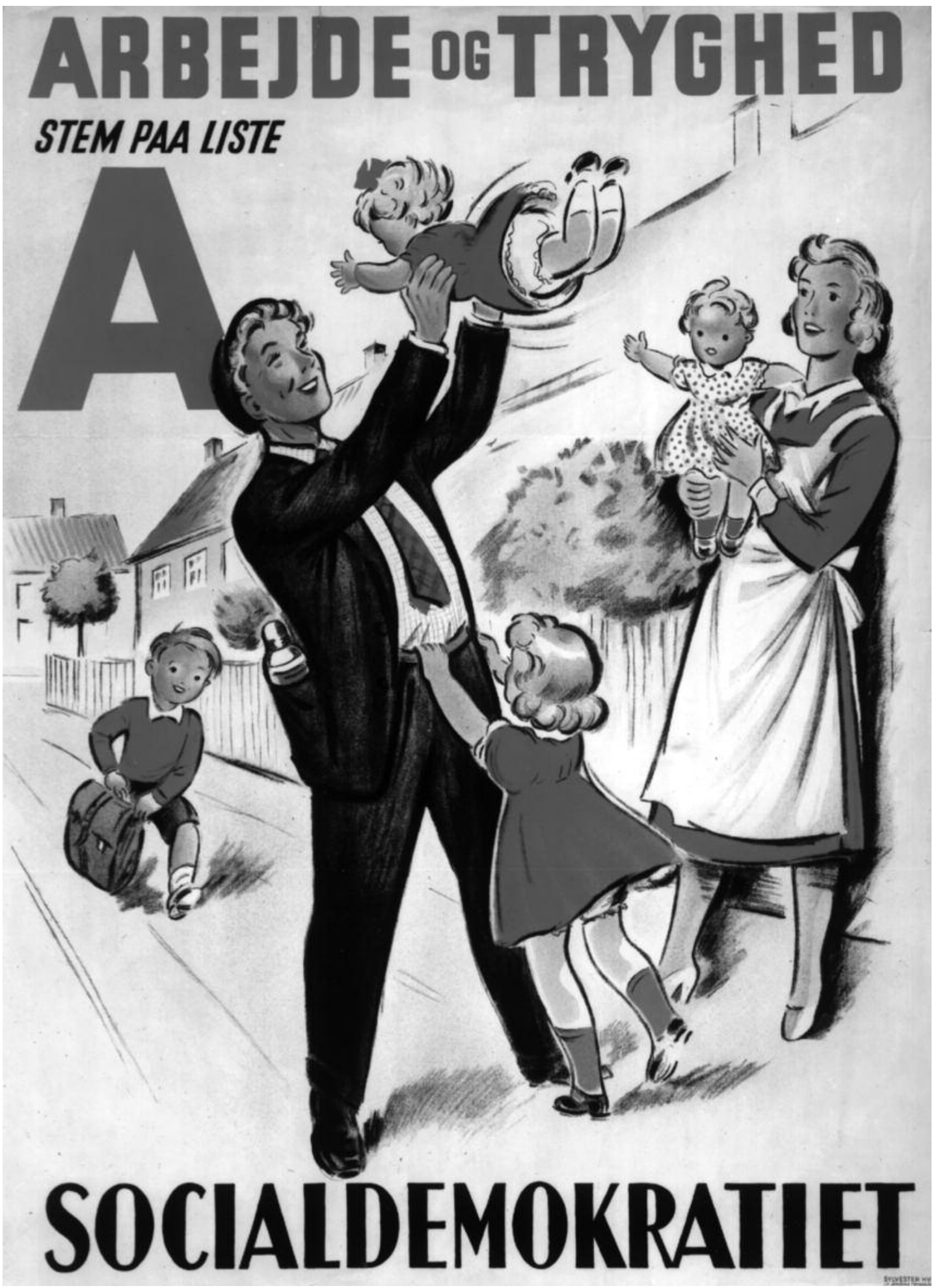

Socialdemokratisk valgplakat fra 1950. (ABA) 


\section{DE KVINDESAGLIGE ORGANISATIONER}

Dansk Kvindesamfund var den kvindesaglige organisation, der mest bevidst og kontinuerligt arbejdede for at fremme kvinders rettigheder. Foreningen blev stiftet i 1871. Efter at kvinde-stemmeretten var vundet i 1915 blev målet at udvikle og dygtiggøre kvinder til den fuldmyndige borgers ansvar, at arbejde for kvinders ligestilling med mænd i famlie, samfund og stat samt at forbedre kvinders og børns vilkår særligt ad lovgivningens vej. Dansk Kvindesamfunds medlemstal i mellemkrigstiden lå på omkring 10.000 og organisationen ekspanderede ikke i perioden (Nielsen 1994). ${ }^{14}$

Medlemmerne bestod både af erhvervsaktive kvinder og af husmødre. Foreningen udførte ofte i samarbejde med andre kvindeforeninger en effektivt lobbyarbejde og mange af de lokale foreninger organiserede oplysningsvirksomhed.

I 1930erne blev alliancen mellem de socialdemokratiske kvinder og Dansk Kvindesamfund konsolideret. Hvor mange kvindesagskvinder tidligere havde været socialliberale (medlemmer af Det radikale Venstre) eller konservative, var der i mellemkrigstiden en håndfuld kvindesagligt engagerede kvinder, der så Socialdemokratiet som løsningen på samfundets og kvindernes problemer. Valget af den unge jurist og socialdemokrat, Edel Saunte, til formandsposten i Dansk Kvindesamfund i 1936 konsoliderede alliancen mellem Socialdemokratiet og Dansk Kvindesamfund. Det betød etableringen af en - også i nordisk og vesteuropæsik sammenhæng - ret enestående alliance. Samarbejdet lagde grunden til et netværk af elitekvinder, en "networking female elite”, som eksisterede langt op i efterkrigstiden. De socialdemokratiske og socialliberale kvinder, som udgjorde kernen i denne alliance var enige på vitale punkter mindst når det drejede sig om ligestilling. Det udmøntede sig i et effektivt lobbyarbejde mod særlige beskyttelseslove for kvinder og for gifte kvinders ret til arbejde. De havde således deres store andel $\mathrm{i}$ at Danmark aldrig implementerede ILO konventionen vedrørende arbejderbeskyttelse i 1919. Ligesom de havde deres andel i, at der aldrig kom et officielt forbud mod gifte kvinders ret til arbejde.

Danske kvinder stod i sammenligning med det øvrige Europa ret stærkt på det offentlige arbejdsmarked. Formelt set i hvert fald. Den nye tjenestemandslov fra 1919, indeholdt bestemmelser om ligeløn for mænd og kvinder i statens tjeneste. Loven var den første af sin art i Europa. Yderligere gav en lov fra 1921 mænd og kvinder lige adgang til offentlige erhverv, militær og præstegerning undtaget.

I 1934 blev "Danske Kvinders Erhvervsraad” etableret i regi af paraplyorganisationen Danske Kvinders Nationalråd. Organisationen spillede rollen som vagtpost og fulgte og dokumenterede ivrigt diskriminationssager på arbejdsmarkedet. Et af erhvervsrådets medlemmer, Anna Westergaard, blev i 1937 formand for The Open Door International, en verdensorganisation for kvinders økonomiske frigørelse.

De kvindesaglige organisationer havde endelig andel i mellemkrigstidens nye myndigheds- og rgteskabslove fra 1922 og 1925. Det betød bl.a. at begge forældre fik myndighed over børn, at mænd og kvinder blev stillet lige i æateskab i forhold til forsørgelse, ejendom og grld og at adgang til skilssmisse blev udvidet.

Dansk Kvindesamfunds sammensathed politisk og geografisk betød at der var grænser for progressiviteten. F.eks. i forhold til tidens hede debatter om en ny seksualmoral og om udvidet adgang til prævention og abort. Her var en del af Dansk Kvindesamfunds medlemmer i overensstemmelse med konservative kvindeforeninger som KFUK, mens de yngre (københavnske) medlemmer var mere radikale og pressede på for seksualpolitiske reformer. Det betød, at Dansk Kvindesamfund aldrig tog et offentligt standpunkt og heller ikke lavede lobbyarbejde for f.eks. seksualklinikker. Dette til 
forskel fra de socialistiske kvindeorganisationer. Ligesom de socialdemokratiske kvinder blev Dansk Kvindesamfund inspireret af de svenske - Myrdalernes - kvalitative befolkningspolitik og prioriteringen af positive moderskabsforanstaltninger. I midten af 1930erne henvendte Dansk Kvindesamfund sig til Befolkningskommissionen og argumenterede for kvalitative løsninger af befolkningsspørgsmålet, herunder oprettelse af flere vuggestuer og børnehaver (Borchorst 1985). Kvinder med tilknytning til Dansk Kvindesamfund var også aktive i de private mødrehjælpsorganisationer, som ved Mødrehjælpsloven i 1939 blev offentligt støttede institutioner.

Alt i alt balancerede Dansk Kvindesamfund mellem ligerets- og særarts interesserne blandt medlemmerne. Størst succes havde organisationen, når det gjaldt ligestilling på arbejdsmarkedet. Her fandt borgerlige liberale og socialdemokratiske kvinder fælles fodslag $\mathrm{i}$ at hindre statslig regulering af arbejdsmarkedet for kvinder, noget, der blev set som kønsdiskriminerende. Dansk Kvindesamfund kritiserede herudover diskriminationen af kvinder som borgere bl.a.i alders- og invalidesager og støttede og initierede nye socialpolitiske initiativer.

Dansk Kvindesamfunds arbejde var fokuseret på det parlamentariske system, som organisationen havde txt kontakt til via sine medlemmer, hvoraf flere var politikere i Rigsdagen eller i de kommunale råd. Samtidig betød den tæette kontakt til samfundets politiske elite og den brede politiske sammensætning, at organisationen var kompromissøgende og moderat. I nogle tilfælde blev den helt handlingslammet f.eks. når det gjaldt seksualreform.

Vurderer man således Dansk Kvindesamfunds indsats i forhold til Koven og Michels parameter om kvindebevægelsens succes, når det gjaldt reformer for kvinder og børn, maternalist politics, er resultaterne i Danmark beskedne. Særskilte foranstaltninger for kvinder - udover barselsorlov - vandt aldrig genklang i Danmark. Den internatio- nale konvention vedrørende kvindearbejde og særlige mødreforanstaltninger, ILO konventionen fra 1919, som i 1920erne inspirerede initiativer $\mathrm{i}$ andre lande, blev aldrig en realitet i Danmark. Det sejrende princip, som også Dansk Kvindesamfund initierede, blev det universalistiske, det vil sige, at offentlige ydelser skulle gives til individer uafhængigt af deres køn.

Men det, der på kort sigt kunne tage sig ud som kvindebevægelsens svaghed, blev måske på længere sigt en styrke? I hvert fald har nyere komparative analyser vist, at det bedst kan betale sig at være kvinde i et samfund af den danske type, hvor velfærdsydelser er baseret på borgerrettigheder og på principper som skattefinanciering og universalisme - og altså ikke på kvinders særart, som mødre og husmødre (Lewis 1995 ).

\section{SAMMENFATNING}

Pointen i hele dette massiv af oplysninger om kvinders organiserede bestræbelser har været at vise, hvorledes kvinder har bidraget til etableringen af den danske velfærdsstat. Kvinderne har bidraget også til velfærdsstatens tidlige historie $\mathrm{i}$ en udstrækning, som gør Kolstrups henvisning til dem, som "velfærdsorganisationer uden betydning for den nationale lovgivning" helt utilstrækkelig og misvisende. Kvindeorganisationerne var på en lang række punkter med i "den langvarige glidende reformproces". De befandt sig ikke alene i velfærdsorganisationer, som stod udenfor, men var også med til at påvirke beslutningsprocesserne.

Desuden blev der, og det er ikke det mindst væsentlige, via kvindeorganisationerne artikuleret vigtigte holdninger både for $o g$ imod en udvidet statsintervention $i$ det private liv og til kvinders deltagelse $\mathrm{i}$ det lønnede arbejde, som er væsentlige for vurderingen af den danske velfærdsstat. Også i sin udfoldede form kom velfærdsstaten i Danmark til at begrænse sig til socialuddannelses- og arbejdsmarkedspolitik og 
altså netop til de områder, hvor kvinderne var aktive og artikulerede.

Samtidig er det klart, at kvindernes indflydelse og radikalitet både blev begrænset af deres beskedne representation i de politiske forsamlinger og af den generelle politiske kultur præget af mange selvstændige og af politiske klassekompromisser. Her har både den liberale selvstændighedskultur og dens skepsis overfor statsintervention, og den restriktive socialdemokratiske partilinje spillet en rolle, som ser ud til på en rakke punkter at gøre Danmark til noget særligt, også i Norden. Sammenlignet med Sverige har krav, der fokuserer forandringer af forhold mellem kønnene, således haft vanskeligt ved at trænge igennem i den politiske kultur. Både dengang og nu.

I 1990ernes danske kønsforskning på feltet køn og velfærdsstat, har der været etableret en modstilling af en politologisk patriarkatsteoretisk tilgang knyttet til en traditionel opfattelse af borgerens autonome politiske rettigheder og så en diskursorienteret tilgang, der betjener sig af Foucaults begreber om den biopolitiske diskursmagt (Sjørup 1997). Til forskel fra disse positioner og tilgange, mener jeg, at denne artikel, som stort set set er fremkaldt via en “informeret" empirisk tilgang, har gjort det muligt at pege på kvindernes bidrag til velfærdsstatens etablering på et niveau, som ofte er fraværende i såvel politologiske som sociologiske analyser.

Såremt tiden og pladsen havde tilladt det, ville jeg med afsæt i det ovenstående have udforsket det symbolske niveau i hele velfærdskonstruktionen og afsøgt, hvordan politisk magt bliver konstrueret omkring kønsdikotomier, selv om den politiske magt langtfra altid handler om køn i bogstavelig forstand. I den internationale offentlighed, associeres socialt engagerede, men relativt svage organisationer og nationer som FN, Nordisk Råd og de nordiske velfærdsstater ofte med bløde værdier og feminitet, i kontrast til mere magtfulde organisationer som
Verdensbanken, WTO og NATO, der associeres med magt og maskulinitet. Hvilke forbindelseslinjer er der mellem de feminint konnoterede nordiske velfærdsstater, og så den hjemlige debat, med dens ofte skjulte kønskonnotationer? Joan Scott taler i sit berømte essay "Gender, a Useful Category of Historical Analysis" om, at politik på højeste niveau, high politics, er et kønnet begreb, fordi det netop etablerer sin høje autoritet i kraft af eksklusionen af kvinder (Scott 1988). Køn er, siger hun videre, en af de referencer, som legitimerer politisk magt. At stille spørgsmål eller at ændre ved denne konstruktion, truer hele systemet.

\section{Noter}

1. Artiklen bygger på indlæg ved 23. Nordiske Historikermøtet Tammerfors 1997: Paneldebatten: Kvinnorörelsen, den glömda folkerörelsen? samt ved et debatmøde i SFAH i 1998.

2. Debatten er opsummeret i Sjørup 1997.

3. Kolstrup 1996 og Den jyske Historiker nr. 82. December 1998.

4. Kønsblindheden er til dels arvet fra andre toneangivende værker velfærdsstatsforskningn, f.eks. Esping Andersen 1990 og Baldwin 1990.

5. 4. Koven, Michel 1990 og 1993. Se også Diane Rothbard Margolis: "Women's Movements Around the World: Cross Cultural Comparisons". In Gender and Society. Vol.7. no.3. September 1993 6. Parrallelle overvejelser er gjort for Sverige i Wetterberg 1997.

7. Indre Missions forgrenede organisationsnet havde i begyndelsen af 1920erne en berøringsflade mellem 400.000 og 500.000 og er blevet betegnet som landets største massebevægelse på dette tidspunkt. Til sammenligning organiserede fagbevægelsen - De samvirkende fagforbund ca. $300.000 \mathrm{i}$ 1918 mens Socialdemokratiets medlemstal var helt nede på 78.000. I 1910erne havde også afholdsbevægelsen med sine 200.000 medlemmer karakter af en massebevægelse. Afholdsbevægelsen var kønsblandet i Danmark, ligesom Indre Mission. Ingen af organisationerne opgjorde medlemmer eller "venner" efter køn, men lokale lister giver grund til at antage, at kvinderne udgjorde i hvert fald halvdelen.

8. F.eks. Margareth Bondfield, der blev den første kvindelige minister i Storbritannien i 1929, samt 
den internationalt orienterede Labour MP, Edith Picton-Turbervill.

9. Den nye Folkeskolelov fra 1937 gjorde husgerning obligatorisk for pigerne ligesom en tre-årig husholdningsundervisning for unge mellem $14 \mathrm{og}$ 20 blev diskuteret.

10. Jeg har andetsteds gjort rede for husholdningsbevægelsens sisyfos arbejde: Det var organisationer, der hvilede på et grundlag, der gradvist forsvandt i og med statsliggørelsen og industrialisering af familiens omsorgsopgaver og ernæringsopgaver og husmoderens symbolske "død". Og at det hektiske arbejde med husholdnings "sagen" må ses i sammenhæng med måden, hvorpå identitet og ideologi gestalter sig i historiske forandrings-processer (Christensen 1993).

11. Den nyeste analyse af det socialdemokratiske kvindearbejde i mellemkrigstiden er Christensen 1998.

12. F.eks var udbygningen af børnehaverne meget beskeden, tallet steg med kun tre om året (Borchorst 1985).

13. Befolkningskommissionen blev nedsat i 1935 . Anledningen var det faldende fødselstal. De tre rapporter fra kommissionen, der kom i årene 1936 -38, omhandlede centrale emner som børnehavespørgsmålet, boligbyggeri og huslejetilskud for børnerige familier og moderens rettigheder i anledning af fødsel og seksualoplysning.

14. En anden måde at anskue denne historie er fra paraplyorganisationen Danske Kvinders Nationalråd. Se Hanne Dam: På trods. 100 års kvindehistorie. Danske Kvinders Nationalråd 1899-1999. København 1999.

\section{LITTERATURLISTE:}

- Baldwin, Peter:( 1990) The Politics of Solidarity. Class Bases of the European Welfare State 18751975, Cambridge.

- Borchorst, Anette: ( 1985)" Moderskab og børnepasning i 30erne." In Hilda Rømer Christensen og Hanne Rimmen Nielse (red): Tidens Kvinder.

Om kvinder $i$ mellemkrigstiden. Århus

- Bridental, Renate (1994): "Die Rolle der organisierten Landfrauen bei der konservativen Mobilmachung in der Weimarer Republik." In Feministiske Studien.vol.12. Mai. 1994. Nr. 1.

- Esping Andersen, Gösta: (1990) The Three

Worlds of Welfare Capitalism. Cambridge.

- Christensen, Hilda Rømer. (1993) Historie, feminisme og poststrukturalisme. In Årbog for Arbejderbevagelsens Historie.
- Christensen, Hilda Rømer(1995): Mellem backfische og pane piger. Kon og kultur $i$ KFUK 19831940. København.

. Christensen, Hilda Rømer: (1998) "Socialist Feminists and Feminist Socialists in Denmark 19201940" in Helmut Gruber and Pamela Graves: Women and Socialism, Socialism and Women, Europe Between the Two World Wars. New York, Oxford. - Christensen, Hilda Rømer, Nielsen, Hanne Rimmen ( 1985): “Arbejdet, der bærer lønnen i sig selv - om landbokvinder, husarbejde og husholdningsideologi i mellemkrigstiden". In Den jyske Historiker. Nr. 34. 1985.

- Den jyske Historiker nr. 82. December 1998. Det nationale velfærd? Den danske velfærdsstat i international belysning.

- Jensen, Sigurd: Københavns historie. Bd. 5. 19001945.

- Kolstrup, Søren: (1996) Velfardsstatens rødder. Fra kommunesocialisme til folkepension. København.

- Koven, Seth, Michel Sonya (1990): "Womanly Duties: Maternalist Politics and the Origins of Welfare States in France, Germany, Great Britain, and the United States 1880-1920." In American Historical Review vol.95.no.4.October 1990. - Koven, Seth, Michel Sonya (eds)(1993): Mothers of a New World: Maternalist Politics and the Origins of Welfare States. London.

- Lewis, Jane (1995): Gender, Family and the Study of Welfare "Regimes". Paper 17. February 1995. Udgivet af: Freia. Department of Development and Planning, Aalborg University.

- Nielsen, Hanne Rimmen (1994): "Den kvindelige karriere i 1920erne". In Adda Hilden og Jytte Larsen: Når baner brydes. Et pilotprojekt om 1920erne til Dansk kvindebiografisk Leksikon. Århus.

- Scott, Joan Wallach (1988): "Gender, a Useful Category of Historical Analysis" In Gender and the Politics of History . New York.

- Sjørup, Karen (1997): "Velfærdsstaten som middel i kvinders magtspil. Govermentalitet og statsfeminisme i den moderne velfærdsstat." In Kvinder, Kon og Forskning. 2. 1997.

- Wetterberg, Christina Carlsson (1997): "Kvinnorörelse och välfärdsstat - Sverige/Schweiz" in B. Gullikstad og K. Heitmann: Kjønn makt, samfunn $i$ Norden i et historisk perspektiv. (Konferencerapport fra det 5.nordiske kvinnehistorikermøtet, Klækken 1996). Skriftserie 2.97. Senter for Kvinneforskning. Norges teknisk-naturvidenskapelige Universitet. Trondheim.

-Wiinblad. E, Andersen, Alsing (1921): Det danske Socialdemokratis Historie fra 1871 til 1921. 


\section{SUMMARY}

Women and The Making of the Danish Welfare State. Women's Associatons in Denmark 1920-1940.

The article deals with womens organized contribution to the making of the Danish Welfare State during the interwar period. It is argued that women contributed substantially to the debate and at the level of decision making. Women's contributions are traced both at the local and at the national levels and documentation derives from a wide range of associations: From conservative, religious ones such as the YWCA to the radical: The Working Women's Association.

In the absence of a strong Social-Demo- cratic women's association, the womens rights movement, The Danish Women's Society, became the nexus for a strong coalition of elite women, a networking female elite, with different political backgrounds. They consolidated a longstanding pattern for cooperation among organized women, which also remained in the period after 1945. The stress in this women's rights community was laid on equality measures, which constituted women as individuals with equal rights rather than as gendered persons and in their capacity as mothers and wives.

Hilda Rømer Christensen

Koordinator for Kvinde- og Kønsforskning i Danmark 